\title{
A CONTEXTUAL METHOD OF INTERPRETING THE QUR'AN: A SEARCH FOR THE COMPATIBILITY OF ISLAM AND MODERNITY
}

\author{
Dede Rosyada \\ Syarif Hidayatullah State Islamic University (UIN) Jakarta \\ dede.rosyada@uinjkt.ac.id
}

\begin{abstract}
The Qur'an, the Holy Book, the guidance for Muslims' lives, was revealed in Arabic. It is believed that Arabic was chosen as the language of the Qur'an, because of its compatibility with and capability of representing the meanings of God's message. As the Qur'an was sent down to the Earth in context, interpreters from time to time need to contextualize it to find out its relevance to the changes and demands of the age.

A contextual approach could be fitted with many methods of interpretation, one of them being thematic interpretation. In its application, this method contextualizes the Qur'an with its first audience, its following generations up to its contemporary audience and interpreters where new practices and information are taken into consideration. The method deploys a linguistic approach and approaches which consider the importance of history and development of discourse. In addition, by applying this approach an interpreter is expected to make the message compatible with the needs of the time and a realistic prediction over its direction in the future.
\end{abstract}

Keywords: Contextualization, Thematic Method, and Linguistic Analysis

\section{Introduction}

The Qur'an was revealed as guidance for all people to get happiness both in this world and in the hereafter. The nature of the Qur'an is open to various interpretations. For instance, the word al qital can refer "to kill in a battle" or "to eliminate other lives" (Dede Rodin, 2016: 51), or "curse" (Rodin, 2016: 50). The word is often understood and interpreted variously following the influence of the context and tendency of an interpreter. He or she does so because of the need of communicating interpretation with his or her audience. An interpreter usually makes his or her own serious effort to come to the meanings that he or she believes to be the appropriate one.

I will illustrate the point above by discussing on of the most debated terms, i.e. ijtihad. According to Ibnu Manzur, as cited by Dede Rodin, the term ijtihad means a serious effort to implement some obligations of God (Rodin, 2016: 44). While Al-Raghib Al-Asfahani, gave three meanings: to endeavor, to face the enemy, to face a devil and to face the lust (Al Raghib al Asfahani, $1412 \mathrm{H}$ : I/87). There is no definite meaning of it. Some radical leaders exploit it to intimidate other peoples, forgetting that it has positive and constructive meanings such as efforts to promote humanity, respect, tolerance, and to develop civilization for human life. Some scholars who use rationalistic approach, see the term positively and understand God's commands contextually to maintain the message of Islam which respects tolerance to difference, harmonious life, collaboration, togetherness, human rights and equality. My view is in line with this group of scholars. If we treat the Qur'an by applying this approach, we will have ample opportunity to take advantage of the Qur'an for promoting harmonious life, progress and better civilization that includes developing science and technology. 
Therefore, an interpreter needs to fulfill certain qualifications in Arabic language sciences as well as other humanistic sciences before he or she interprets the Qur'an. Mastering these requirements helps him or her in disclosing rational understanding the Qur'an which is relevant to social needs, and social change. It is believed that the Qur'an was revealed in anticipative form and substance of message which is interpretable to answer changes, progress over times. However, historical evidence indicates that based on two ways of lexical and sociological approaches, the task of interpreting the Qur'an requires different ways. Abdullah Saeed identified three broad approaches in relation to the interpretation of the Qur'an in the modern period, textualist, semi-textualist, and contextualist (Abdullah Saeed, 2006, 3). This classification is based on the linguistic criteria as well as the socio-historical context of the Qur'an in determining the meaning of the text. The textualists deploy exclusively literal approach over a text, and they consider the meaning of the Qur'an as having universal message. Meanwhile, semi-textualists also use textual approach over the text. At the same time they also apply sociological perspective over the discussed context in order to gain the most compatible interpretation with real contemporary human life. How to develop such model of interpretation? That is the main issue to be elaborated in this paper.

\section{Contextualization of the Qur'anic Interpretation}

To apply a contextual reading of the Qur'an, an interpreter is expected to take into consideration, at least, two following points:

1. Understanding the linguistic aspect of the text of the Qur'an, its internal aspects, and its externals ones (Fadlan Mohd Othman, 2011: 428);

2. Interpreting the Qur'an by considering the following views: the Prophet Muhammad, his Companions, and his followers as the recommended generation by the Prophet. In addition, he or she is advised also to consider the views of prominent religious scholars. Finally, he or she is hoped to consult also information from his or her context, and blend all information to construct the Qur'anic message which is relevant to the present time to meet its most benefit for human lives now and anticipative over the need in the future time (Hasba Al-Rasul Al-Abbas Muhammad, 2007: 19).

Some of the Prophetic Hadiths may literally be looked irrelevant to be used in interpreting the Qur'an today. However, these Hadiths can be rationalized by contextualizing them into its revelation time when the Prophet for the first time dealt with the revealed verse in which these Hadiths were considered the initial interpretation of the verse. For the present usage, an interpreter still can deploy the Hadiths by disclosing its substantial meaning to find dimensions which are fitted with the present situation. By tackling the Hadiths in interpreting the Qur'an in such a way, Muslim leaders, for instance, can reformulate some new humanistic religious opinions to guideline social life of Muslims. They can interpret the Qur'an by relating the texts to a certain situation without analogizing it to the same situation at the prophet period to find some religious opinions. That is a lingua-humanistic approach to interpret the Qur'an. In addition, human life is always changing, in the social life, culture, professionalism, and human relation within Islamic society and with the different religion followers. All those progresses need to be guided by religious doctrines and religious opinions from Muslim leaders as the heirs of the prophet, by the inclusive, pluralistic and humanistic guidelines as Prophet Muhammad did in his period. That is why, the contextual and humanistic interpretation could be proposed as an alternative to the effort of Muslim scholars as well as Muslim leaders to make Islam relevant to the demand of time.

The contextual approach in interpreting the Qur'an is actually a school of Qur'anic hermeneutics which uses linguistic approach in its procedure of analysis in 
gaining the suited meanings with the context of readers or interpreters. In line with it, Abdullah Saeed emphasizes that interpreting the Qur'an needs to take social change into account in order to sustain the close relationship between the Holy Book and the Muslim today (Muhammad, 2007: 4). This is a contextual method of interpreting the Qur'an. It does not ignore textual analysis, because every single word in the Qur'an has specific message of Allah. He has chosen the Arabic language to accommodate His messages. The Arabic language has rich vocabularies, literature, and even semantics reference that can help in understanding the Qur'an context. Tamam Muhammad al Sayid emphasized in his thesis that language is always changing because of the social and culture development. And there are three focuses of linguistic analysis in interpreting Qur'an: 1) Analyzing the meaning of the new reference of Qur'an which was not acknowledged in the pre-Islamic period, 2) Contextualizing the meaning of the Qur'an by considering the context of its revelation, and maintaining the Arabic syntactic, 3). Analyzing some new Arabic terms and items used by the Qur'an and not used in pre-Islamic language tradition (Tamam Muhammad al-Sayyid, 2010: 4).

Meanwhile, Quraish Shihab, one of the Indonesian modernist interpreters, proposes a theory of linguistic analysis -thematic and descriptive methods. For him, thematic analysis needs understanding of the words and elements of the Qur'an. To get a comprehensive understanding of the Qur'an, an interpretation process should be supported by linguistic analysis, that is searching for the meaning of the words, and also the meaning of the context of the verses at whole (Muhammad Quraish Shihab, 2013: 179). He looks at two aspects of linguistic analysis: the meaning of the words, and the meaning of its usage in the context of the verses. Tabataba' $i$, on the other hand, pays attention to the stylistic of the text, the purposes of the verses in using the words (Rahmat Allah Abd Allah Zadeh, Mohammad Javad Saadi, Mahmood Khosravi: 2013, 3118). Both prominent scholars actually have the same perspective to understand the meaning of the words, that every interpreter should take account the context of the verses of Qur'an. Considering the context of verses can be seen on two aspects: the meaning of the words according to the relevant event or case that happened when the words were revealed, and secondly, the meaning of the words according to the context of the verses at whole. By looking at these two aspects, the interpreter can formulate the Qur'an message in a comprehensive way.

It is understandable, that interpreting Qur'an in the scheme of contextual approach needs persistently linguistic approach to understand the meaning of the words, whether lexical or the context of the words in each verse. The most important aspects of such interpretation are understanding Arabic vocabularies. Dalal Binti Kuwairan, a graduate of the University of Umm al Qurra explained in her dissertation, that linguistic approach is a direct understanding toward the words of Qur'an, and all those interpretations have been existing in a lot of ancient exegeses books, and were written by prominent scholars and mostly referring to the opinions of the Prophet companions and their followers. They actually understand Arabic languages well which were used by God to accommodate all His messages in early period of Islam. Modernizing the interpretation of the Qur'an can be understood as the effort to rationalize the meaning of Qur'an by analyzing the use of the words in diverse contexts, and the context of words in each verse, and going further tracing the opinion and practices of the Prophet companions and their followers (Dalal, 2014: 56). This method operationally collects the stipulated meaning of Qur'an words, and choosing the most relevant meaning in terms of the Prophet Tradition, the linguistic pattern and development of culture and human beings. Furthermore, the current prominent scholars are having the same authority to interpret the words of Qur'an, when they aren't finding any interpretations from the prophet 
companions and their followers, by linguistic approaches: grammatical or literary (Dalal, 2014: 56).

Beyond all these procedures, contextualization of the Qur'anic interpretation precisely needs a sociological analysis, whether in the context of fulfilling all the needs of the people behavior in all areas, professional, social, economy and even in a political life, or to examine and to judge the existing traditions, cultures and relationship in all the human life, just to guide the people to the right paths. Bringing the Qur'an down to the Earth and influencing people behavior in all of their work areas aren't easy. We need a comprehensive explanation, the clear instruments, and supervision system. All these endeavors are taken into consideration by prominent Muslim scholars to interpret the Qur'an in the way of contextualization, that is the interpretation that takes into account the social development, and social environment. Hasan Hanafi, as Ade Jamaruddin cited, used the name Manhaj al-Ijtima fi al Tafsir. The method is usually used to interpret the Qur'an by relating the text to the reality, and the reality to the text (Ade Jamaruddin, 2015: 6).

Apparently, contextualization of the Qur'an, and manhaj al ijtima fi al tafsir (the analytical method of social phenomena in the Qur'anic interpretation) has the same purpose in bringing the Qur'an guidance for human beings. Along with these ideal missions, both methods can be applied in the application of thematic approach, because it focuses on social engineering or social change based on the Qur'an guidance. As Islam Dayeh explains that the emergence of similar themes in several surah (chapters) are complementarity, and this is a significant aspect of Qur'an composition, that a surah complements another surah (Islam Dayeh, 2010: 478). Hasan Hanafi argues that thematic interpretation is based on the premise that there is no true or false interpretation, and that the validity of an interpretation lies in its power (Rotraud Wielandt, 2008: $<$ http://www.brillonline.n1/subscriber/entry?entry=q3 COM-00059 $>$ ). That is the significance of thematic approach, because it has a power in guiding the human life, and it is relevance to the character of the Qur'an that is complementarity one to another. In spite of these approaches, Contextualization isn't new method. It is just a new orientation of the Qur'an interpretation, by inserting the present-day human needs in interpreting process, and even in some cases involving the empirical human life to be considered in the analysis of interpreting some certain verses of Qur'an.

Hence, the process of interpretation is following the procedure of thematic approach, formulating the focus of study and its goals, identifying themes of the verses of the Qur'an, analyzing the meaning of the words in these verses, and the meaning of the verses based on its context, in the lexical, the context of the inherent verses, correlation between verses, and socio-historical analysis of those verses, the events or cases happening when the verses were revealed. These aspects should be taken into consideration in the process of understanding the meaning of the Qur'an. To contextualize the interpretation, Hasan Hanafi, emphasizes that when the interpreter has obtained certain meaning of some accumulated and correlated verses, he/she then should continue by analyzing the needs of the society in such focus, and what are the related cases happening to be influenced by the light of God. It is expected to formulate the new interpretation adhering the culture of the community, the ways of thinking, behavior, and moral attitude, the present-mindedness and the future. This should be followed by comparing the new formulation with the empirical existence of the people's tradition. Finally, the interpretation should end by the description of action (Ibid., 7). 


\section{Conclusion}

The contextual method of Qur'anic exegesis is not new. It orients an interpreter to consider how people need the guidance of the Qur'an in their social interaction and social relationship. It also directs them to criticize the current culture which reflects having bad influence to our lives, or helps us to engineer the future, whether in the context of professional works, economy, politics, or in the context of social relationship, family life, brotherhood or kinship. The thematic approach instead of descriptive model is considered appropriate to apply contextual method of the Qur'anic interpretation, helping an interpreter to get the focus of explanation straight to the discussed cases, and to maintain the explanation in the focus until procedures of action. The analysis is started by linguistic understanding to get meaning of the words and the context of the structure of the words in each verse, to be followed by the analysis of the socio-historical contexts when the Qur'an was revealed, and the sociological contexts when such words and verses are interpreted, to find out the new formulation of religious opinions related to the new situation. Finally, the new interpretation with the strong orientation for humanistic approach, by taking account the needs of human beings today and tomorrow, on science, social, politics, economy, family life, and kinship, will be able to be figure out and will be enlightening all Muslim followers.

\section{References}

Asfahani, al Raghib, al. 1412. Mu'jam al Mufradat Li Maani alfadz al Qur'an, Dar al Qalam, Damaskus.

Dayeh, Islam. 2010. Al Hawamim: Intertextuality and Coherence in Meccan Surah, at the Angelika Neuwirth, Nicolai Sinai, and Michael Marx (ed.), The Qur'ān in Context, Historical and Literary Investigations into the Qur'ānic Milieu, Brill, Leiden.

Jamaruddin, Ade. 2015. Social Approach in Tafsir al-Qur'an Perspective of Hasan Hanafi, Jurnal Ushuluddin Vol. 23 No. 1.

Muhammad, Hasbi al Rasul, al Abbas. 2007. al Madkhal ila Manahij al Mufassirin, Majalah Jami'ah al Qur'an wa al Ulum al Islamiyah.

Othman, Fadlan, Moh, Mohamad Zaid Mohd Zin, 1Ahamad Asmadi Sakat, 3Mohd Roslan Mohd Nor, 4Mohd Arip Kasmo, 1Mohd Najib Abdul Kadir, 1Jaffary Awang, 1Latifah Abdul Majid, 2011. Interpretation Methodology of Al Shaykh 'Abd Al-Rahman Al Sa'di In His Taysir Al-Karim Al Rahman Fi Tafsir Kalam Al-Mannan, Advances in Natural and Applied Sciences, 5.

Rodin, Dede, Islam dan Radikalisme. 2016. Telaah atas Ayat-ayat "Kekerasan" dalam al-Qur'an, Jurnal ADDIN, Vol. 10, No. 1.

Saeed, Abdullah. 2006. Interpreting the Qur'an, Towards a Contemporary Approach, Routledge Taylor and Frances Group, London and New York.

Sayyid, Tamam, Muhammad al. 2010. Alfadz Wa Tarakib wa Dalalah jadidah fi al Siyaq al Qur'any, al jami'ah al Syarq al Ausath, Temuz, Afrika Utara.

Shihab, M. Quraish. 2013. Membumikan al-Qur'an: Fungsi Dan Peran Wahyu Dalam Kehidupan Masyarakat. 2/new ed. Bandung: Mizan,

Sulamy, Dalal binti Kuwairan bin Huwaimil al Baqilany. 2014. al Tajdid fi Tafsir fi al Ashri al Hadits, Mafhumuhu, Wadhawabituhu wa al Tijahatuhu, Program Studi Tafsir dan Ilmu-ilmu al Qur'an, University Um al Qurra.

Wielandt, Rotraud. "Exegesis of the Qur'ān: Early Modern and Contemporary ." Encyclopaedia of the Qur'ān. General Editor: Jane Dammen McAuliffe, Georgetown University, Washington DC. Brill, 2008. Brill Online. DUKE 
UNIVERSITY.

11

February

2008

$<$ http://www.brillonline.nl/subscriber/entry?entry=q3 COM-00059

Zadeh1, Rahmat Allah Abd Allah, Mohammad Javad SAADI2, Mahmood Khosravi, Comparing the Quran by Quran Interpretation Method in Al- Mizan as well as Al-Tahrir, and Al- Tanvir, International Research Journal of Applied and Basic Sciences (C) 2013 Available online at www.irjabs.com ISSN 2251-838X / Vol, 4 (10): 3114-3123 Science Explorer Publications, p. 3118. 